IZA DP No. 7546

Older Workers and Working Time

David N.F. Bell

Alasdair C. Rutherford

August 2013

Forschungsinstitut zur Zukunft der Arbeit Institute for the Study of Labor 


\title{
Older Workers and Working Time
}

\author{
David N.F. Bell \\ University of Stirling, \\ Centre for Population Change and IZA
}

\author{
Alasdair C. Rutherford \\ University of Stirling
}

\section{Discussion Paper No. 7546 \\ August 2013}

\author{
IZA \\ P.O. Box 7240 \\ 53072 Bonn \\ Germany \\ Phone: +49-228-3894-0 \\ Fax: +49-228-3894-180 \\ E-mail: iza@iza.org
}

\begin{abstract}
Any opinions expressed here are those of the author(s) and not those of IZA. Research published in this series may include views on policy, but the institute itself takes no institutional policy positions. The IZA research network is committed to the IZA Guiding Principles of Research Integrity.

The Institute for the Study of Labor (IZA) in Bonn is a local and virtual international research center and a place of communication between science, politics and business. IZA is an independent nonprofit organization supported by Deutsche Post Foundation. The center is associated with the University of Bonn and offers a stimulating research environment through its international network, workshops and conferences, data service, project support, research visits and doctoral program. IZA engages in (i) original and internationally competitive research in all fields of labor economics, (ii) development of policy concepts, and (iii) dissemination of research results and concepts to the interested public.
\end{abstract}

IZA Discussion Papers often represent preliminary work and are circulated to encourage discussion. Citation of such a paper should account for its provisional character. A revised version may be available directly from the author. 


\section{ABSTRACT}

\section{Older Workers and Working Time*}

Contrary to much of the established literature, this paper finds that though many older workers would prefer to reduce their working hours (the overemployed), there is a significant group who would like to work longer hours (the underemployed). And contrary to the assumption that the self-employed are more easily able than employees to select a desired combination of hours and the wage rate, this paper finds that older self-employed workers are more likely to wish to adjust their hours, both upward and downward than are employees. A new index of underemployment is used to show that for the UK, since the onset of the Great Recession, underemployment among older workers has been growing more rapidly than unemployment. Using longitudinal data from the UK Labour Force Survey, the paper investigates the effects of overemployment and underemployment on transitions from employment and self-employment into other labour market states. It confirms that overemployment is a significant predictor of retirement among employees while underemployed employees are less likely to retire.

JEL Classification: J01, J11, J21, J22, J23, J38, J64

Keywords: retirement, working time, overemployment, underemployment, self-employment

\section{NON-TECHNICAL SUMMARY}

Older workers are becoming an increasingly important part of the European labour market. Previous literature tended to assume that older workers prefer to work fewer hours. We show that in the UK there are significant number of older workers who want to work for more hours and that the proportion who want more hours has been increasing, particular since the start of the recession in 2008. Our analysis shows that those who want to work fewer hours are more likely to retire early, while those who want more hours delay their retirement compared with otherwise similar workers. We also show that self-employment is more likely among older workers than the young. Some of these may be "necessity" self-employed - they opt for self-employment because they cannot find a job. Although one might expect that they can choose their hours, the self-employed are more likely than the employed to want to either increase or decrease their hours. Because of the growing importance of the labour market for older workers, there is a need to better understand what policy interventions might improve its operation.

\section{Corresponding author:}

David N.F. Bell

Department of Economics

University of Stirling

Stirling, FK9 4LA

United Kingdom

E-mail: d.n.f.bell@stir.ac.uk

\footnotetext{
*Article submitted to the Journal of the Economics of Aging.
} 


\section{Introduction}

Over the next 30 years, the EU working-age population will shrink by 1 to 1.5 million a year. The number of people aged 60 and over will increase by about 2 million a year. Based on historic retirement ages, this implies a significant increase in the old-age dependency ratio. In these circumstances, there is a need to ensure that the potential of older workers is fully realised. One approach is to extend working life: the prospects of increased life expectancy, along with the fiscal problems associated with the recent recession, have caused several countries to propose increases in statutory pension ages. Germany plans to increase the retirement age from 65 to 67 between 2012 and 2029. Japan is gradually increasing the age of retirement from 60 to 65 . France plans an increase from 60 to 62 over the next 8 years. The UK proposes an increase from 65 to 66 in 2024 and to 68 in 2044, while the US proposes to increase its retirement age from 66 to 67.

Increasing the statutory retirement age provides an inducement, but no guarantee, that the effective age of retirement will increase. Working conditions for older workers will influence the effective age of retirement. One important aspect of working conditions is weekly hours of work, also known as working time. Not being able to realise their desired combination of working time and income may cause older workers to change their retirement date. Another possibility is that those out of equilibrium in respect of working time and income from employment opt instead for self-employment where it is commonly believed that they have greater control over working conditions.

The previous literature has focussed on cases where older workers feel that they are providing more hours than they would optimally choose. It has neglected the case where older workers wish to provide more hours than are currently on offer. In addition, the interaction between 
hours of work and self-employment has tended to be ignored, based on what we believe is the mistaken view that the self-employed always work their desired hours. The effects of these issues on retirement decisions have largely been neglected.

Our paper focusses on working time and the retirement decision and extends the previous literature in this area by accommodating the case where older workers are hours constrained in the sense of underemployment (working fewer hours than they desire), rather than overemployment (working more hours than they desire). It also argues that, contrary to the belief that the self-employed can always optimise their working time, older self-employed workers may be either underemployed or overemployed. We believe that there is strong empirical evidence to support this view. Our paper also uses data from the UK Labour Force Survey to derive a new index of the extent of underemployment/overemployment of older workers and provides estimates of the effects of overemployment and underemployment on the retirement decision. Finally it exploits the longitudinal structure of the Labour Force Survey to identify whether overemployment or underemployment are significant predictors of changes in labour market state for both employed and self-employed older workers.

The paper is structured as follows: in the next section, we review the relevant literature on older workers' labour market participation, focussing particularly on its interaction with hours of work and self-employment. Next, we describe our data and derive our index of net overemployment. The following section discusses our analysis of the effects of overemployment and underemployment on transitions between employment, selfemployment and retirement. The final section concludes.

\section{Literature Review}

In many developed countries, the experience of retirement is abrupt. Workers experience a cliff-edge effect in relation to their working time, which falls dramatically between their last 
week of employment and their first week of retirement. Most retirees would prefer to exert control over their retirement process, but this tends not to happen due to inertia in employment practices and the vagaries of pension regulations (Vickerstaff et al. 2004). The extensive variation in effective retirement ages between countries suggests that there may be substantial differences between countries both in employer practices and pension regulations. Eichorst (2011) points out that Germany has successfully increased the employment of older workers in the last decade by removing incentives to early retirement, activation strategies, enhanced training for older workers and reducing subsidised part-time working. However, in many countries older workers are still more likely to be made redundant (Meadows 2003), causing "involuntary” early-retirement. For older workers wishing to defer retirement and/or enhance their pension, one response to unemployment caused by redundancy may be “necessity” self-employment (Block and Koellinger 2009), resulting in relatively low jobsatisfaction. The "necessity” aspect of self-employment may result from age discrimination and employment protection legislation which make employers risk averse in hiring older workers (Adams 2004, Lahey 2006). Reality often falls short of the policy ideal of continuing mutually-beneficial engagement of older workers in the labour market.

One key aspects of this engagment is working time. It has been argued that older workers prefer shorter hours, and if these are not offered by their employer, then they may retire earlier than they might otherwise have done. It is worth noting that retirement is not necessarily an absorbing state. Kanabar (2012) finds that "unretirement" is relatively common in the UK and is driven by factors such as unexpected debt shocks, having a spouse in the workforce, being in good health and having a long-term financial planning horizon.

The role of working time disequilibria driving early retirement is highlighted by Charles \& DeCicca (2007) and by Gielen (2008). Their work derives from a more general literature focussing on supply-side disequilibria (Moffitt 1982, Naylor 2003). The model against which 
they compare is one where workers, whose utility function depends solely on hours and the wage, can costlessly maximize utility by selecting between firms offering different combinations of wages and working time. Moffitt imagines a situation in which firms impose minimum hours constraints. One possible rationale could be limitations imposed by production technology. Those with desired hours above the constraint can attain their firstbest outcome. Those with desired hours below the constraint then choose between participation and a sub-optimal hours-wage combination. Naylor argues that firms may have local market power which they use to push employees off their labour supply curve. Employees then select along a contract curve defined by the firm's iso-profit function and the worker's utility function. The key prediction is that, along this contract curve, workers provide more hours than they would optimally choose.

Charles \& DeCicca develop a model using a simple Taylor series expansion of the difference between actual and desired (optimal) working time. Denote actual hours by $h$, desired hours by $h^{*}$ and partial derivatives of the utility function by $U_{h}$ etc. Then expanding around the optimal level of hours, we have

$$
\begin{aligned}
U(h) & =U\left(h^{*}\right)+\left(h-h^{*}\right) U_{h}\left(h^{*}\right)+\left(h-h^{*}\right)^{2} U_{h h}\left(h^{*}\right) \\
& =U\left(h^{*}\right)-\kappa\left(h-h^{*}\right)^{2}
\end{aligned}
$$

since $U_{h}\left(h^{*}\right)=0$ by definition. In relation to this paper, the interesting aspect of this argument is that it is symmetric. Reductions in utility occur due both to positive and to negative deviations of actual hours from their optimal value. Though Charles and DeCicca focus their empirical analysis on workers being constrained to provide more hours that they desire, equation (1) encompasses both the case of overemployment (desired hours less than actual hours) and that of underemployment (desired hours exceed actual hours). The case of underemployment is also consistent with Kanabar's finding of “unretirement”. This effect 
occurs perhaps due to inadequate information about retirement: some retirees decide that some hours of work is preferable over zero hours.

Gielen utilises a traditional supply framework and argues that the disutility of work increases with age. Her analysis of overemployment among older workers is also driven by the imposition of minimum hours constraints by employers. Though these constraints are not explained, technological or organisational constraints and/or employer market power are possible rationales.

Gielen excludes the self-employed from her analysis, arguing that they are free to set their working hours. This would certainly follow from the standard labour supply model where workers derive utility solely from leisure and consumption (see e.g. Pencavel, 1986). However, a number of studies (e.g. Oswald and Blanchflower, 1998; Blanchflower, 2000; Hundley, 2001; Benz and Frey 2008) suggest that the self-employed derive utility from the increased control they have over their working conditions compared to the employed. Selfemployment is associated with greater independence and creativity than employment, neither of which features in the standard model. Using different terminology, Benz and Frey (2008) argue that self-employment provides "procedural” utility implying that for this group, their utility functions extend beyond outcomes - hours of leisure and wages - to include the processes and conditions of work.

Age, sex, education, and marital status are consistently strong predictors of self-employment (Fairlie and Meyer, 1996; Blanchflower, 2000; Lombard, 2001). It is also the case that the self-employed are more likely to be drawn from the tails of the income distribution. Åstebro et al (2008) argue that this may reflect the self-employed being drawn from two populations, one of which is able to pursue novel opportunities, while the other enters self-employment 
due to unfavourable events or circumstances. The latter are the "necessity entrepreneurs" (Block and Koellinger 2009) already discussed.

Why is this discussion relevant for older workers? There are two main reasons. First, it calls into question the standard model of labour supply as a description of the choices made by older self-employed workers. It also weakens the notion that the self-employed will always work the hours that are consistent with this model. Thus, even conditioning on their other characteristics, the employed and self-employed may choose to retire at different times since they derive different levels of procedural utility from their work. And among the selfemployed, necessity entrepreneurs may find themselves demand-constrained: joint maximisation of procedural and outcome utility may result in deviations of actual from desired hours if the extended choice set is not continuous.

Second, older workers are not exempt from adverse or unexpected events. Kanabar (2012) highlights the effects of unexpected changes in wealth on "unretirement". Older workers are more likely to be made redundant (Matthews 2003). We also know that financial literacy plays an important role in preparedness for retirement (van Rooij et al 2012) and that levels of financial literacy vary across the population, implying that there is a significant probability that pension expectations are not realised. Thus, while the existing literature tends to focus on older workers who wish to reduce their hours, there may be circumstances in which older workers in employment wish to increase their hours or, in extremis, as Kanabar has suggested, for retirees to return to the labour market.

Older workers are more likely to be self-employed. The literature that focusses on the effects of working time on older employees' retirement decisions therefore provides only a partial view. Self-employment is particularly common among those workers older than the state retirement age. In the UK in 2012, 17.8 per cent of the economically active aged 50 to 64 
were self-employed, while for those above aged above the retirement age of 65, 32.5 per cent of the economically active were self-employed and 43.2 per cent of those working at age 70 and above were self-employed. Total employment among those aged 65 plus increased by 120 per cent between 1992 and 2013 to almost 1 million, while the population in this age group increased by 23 per cent over this period. (Source: Labour Force Survey). Workers aged above the statutory retirement age are becoming an increasingly important group within the UK labour market.

High rates of self-employment among this group reflect a number of selection effects, including health, job satisfaction, retirement and pension regulations. Nevertheless, if agespecific probabilities of self-employment do not change, increases in the state retirement age are likely to lead to increasing shares of the self-employed among the older workforce.

In the next section we address the issue of working time, retirement and older workers empirically. We apply our analysis to both the employed and the self-employed, implicitly acknowledging that the "necessity" self-employed may face demand constraints, and that the self-employed also face a dilemma in that they value their leisure, but also the "procedural" utility that they derive from work.

We also consider transitions between employment, self-employment and retirement and how these are affected by working time disequilbria. Fuchs (1982) examines transitions between employee and self-employment status and between working and retirement. Using US data and two-yearly transitions data, he finds that older male employees commonly switch to selfemployment to reduce their hours, particularly after eligibility ages set by Social Security. Both Charles and DiCacca and Gielen use panel data to investigate the effects of overemployment on labour market status. We use a large UK panel to investigate the effects 
of both overemployment and underemployment on the labour market transitions of older workers.

\section{Older Workers Actual and Desired Hours: Some Facts}

For our empirical analysis we use the UK Labour Force Survey. Each quarter, a sample of around 42,600 responding (or imputed) households in the UK is collected, representing about $0.16 \%$ of the UK population. Appropriately weighted, this survey is used to produce all major published labour market aggregates for the UK. Information on respondents' labour force participation is collected each quarter, including whether they would prefer to work shorter (longer) hours at the same pay rate and, if so, how many fewer (more) hours they would like to work. These questions are asked both of the employed and self-employed. We begin the analysis by setting out some major labour market aggregates, with a particular focus on workers aged 50 and above, including some which extend beyond state retirement age, which for men has been 65 throughout our sample period and for women was 60 until 2010. It has been gradually rising since then and will reach 63 in 2016.

Table 1 sets out employment to population (EPOP) ratios for five age groups for the years 2002, 2007 and 2012. These years have been selected both to span a decade over which Labour Force Survey data were collected consistently and to contrast a period (2002-2007), when the UK economy was growing at close to its historic trend growth rate, with a period (2007-2012) where the UK economy was in recession resulting in higher unemployment, lower real wages and, of particular interest for our study, changes in the demand and supply of working time. The age groups have been selected to reflect youth (ages 16-24), prime age (ages 25-49), older workers below state retirement age (50-64), those just above current retirement ages (ages 65-69), and those aged above any current proposed retirement age $(70+)$. 
Table 1: Employment/Population Ratio

$\begin{array}{lrrcc}\text { Age Group } \backslash \text { Year } & 2002 & 2007 & 2012 & \text { Growth } 2002-2012 \\ 16-24 & 58.9 \% & 54.6 \% & 47.3 \% & -19.7 \% \\ 25-49 & 71.3 \% & 71.0 \% & 69.6 \% & -2.4 \% \\ 50-64 & 51.5 \% & 53.3 \% & 53.4 \% & 3.6 \% \\ 65-69 & 7.8 \% & 10.2 \% & 12.4 \% & 60.6 \% \\ 70+ & 1.5 \% & 1.7 \% & 2.2 \% & 49.2 \%\end{array}$

Source: UK Labour Force Survey 2002 to 2012

The EPOP ratios show sharply declining participation among the young due to increased educational participation and worsening employment prospects; a slight decline among prime-age workers mainly during the 2007-2012 recession and substantial increases in the participation of those aged 50+, particularly those in the 65-69 age group.

Table 2 shows the self-employment to population ratio (SEPOP). SEPOP rates increased for all age groups between 2002 and 2012, including during the recession. As a share of the population, self-employment peaks in the 50-64 age group, but the most substantial increases in self-employment were among those above state retirement ages.

Table 2: Self-Employment/Population Ratio

$\begin{array}{lcccc}\text { Age Group } \backslash \text { Year } & 2002 & 2007 & 2012 & \text { Growth 2002-2012 } \\ 16-24 & 1.8 \% & 2.3 \% & 2.5 \% & 41.4 \% \\ 25-49 & 9.4 \% & 10.2 \% & 10.5 \% & 12.1 \% \\ 50-64 & 10.6 \% & 11.5 \% & 12.4 \% & 16.7 \% \\ 65-69 & 1.5 \% & 1.7 \% & 2.2 \% & 49.2 \% \\ 70+ & 1.0 \% & 1.4 \% & 1.9 \% & 88.3 \%\end{array}$

Source: UK Labour Force Survey 2002 to 2012

Table 3 shows actual hours worked (including those in any second job) by age group and employment status. The young work fewer hours than prime age workers and their weekly hours have declined over time, irrespective of whether employed or self-employed. And while the number of self-employed older workers has been increasing, their average hours 
have declined. This contrasts with older employees whose average weekly hours increased between 2002 and 2012.

Table 3: Actual Weekly Hours

\begin{tabular}{lcccccc}
$\begin{array}{l}\text { Year } \\
\text { Age }\end{array}$ & \multicolumn{2}{c}{2002} & \multicolumn{2}{c}{2007} & \multicolumn{2}{c}{2012} \\
Group & employee & $\begin{array}{c}\text { self- } \\
\text { employed }\end{array}$ & $\begin{array}{c}\text { employee } \\
\text { self- } \\
\text { employed }\end{array}$ & $\begin{array}{c}\text { employee } \\
\text { employed }\end{array}$ \\
$25-49$ & 28.9 & 34.8 & 28.6 & 33.4 & 27.5 & 28.5 \\
$50-64$ & 33.3 & 38.3 & 33.2 & 36.7 & 33.2 & 35.5 \\
$65-69$ & 31.0 & 34.5 & 31.3 & 33.3 & 31.6 & 32.8 \\
$70+$ & 19.2 & 23.4 & 20.7 & 22.4 & 22.0 & 22.8 \\
& 15.2 & 18.2 & 15.6 & 21.6 & 17.2 & 19.5
\end{tabular}

Source: UK Labour Force Survey 2002 to 2012

Table 4 addresses the issue of hours constraints. For this we rely on questions asked in the Labour Force Survey each quarter. Respondents are asked "Whether [he/she] would like to work longer hours, at current basic rate of pay, given the opportunity”. Those who say they want to work longer hours are then asked how many extra hours they wish to work. Another question asks whether they would prefer to work shorter hours than at present in their current job. Those who wish to reduce their hours are then asked how large a reduction in their working time they would like to make. Answers to these questions are weighted by the appropriate population weights supplied with the Labour Force Survey.

Table 4a shows the proportion of workers that wish to work longer hours at their current wage, while Table 4b shows the proportion of workers who wish to work fewer hours. What is immediately clear is that there are only small differences in the proportions of the employed and the self-employed who wish to change their hours. Age has a larger influence on desired working time than does employment or self-employment status. Compared with young workers, older workers are less likely to want to increase their hours, and more likely to wish to reduce their hours. But it is clearly not true that older workers only face a lower bound on their working hours. An increasing proportion wishes to extend their hours. 
Possible explanations include improved health reducing the disutility of working time for older workers and increases in unexpected shortfalls in pension values, reflecting the funding difficulties of funding pensions (in the last decade, all of the companies in the UK FTSE 100 index with defined benefit pensions plans have abandoned these schemes).

Table 4a: Proportion Who Wish To Work Longer Hours at Current Wage

\begin{tabular}{lcccccc} 
Year & \multicolumn{2}{c}{2002} & \multicolumn{2}{c}{2007} & \multicolumn{2}{c}{2012} \\
Age Group & employee & $\begin{array}{c}\text { self- } \\
\text { employed }\end{array}$ & $\begin{array}{c}\text { employee } \\
\text { self- } \\
\text { employed }\end{array}$ & $\begin{array}{c}\text { employee } \\
\text { employed }\end{array}$ \\
$25-49$ & $12.5 \%$ & $11.7 \%$ & $13.1 \%$ & $17.9 \%$ & $20.0 \%$ & $22.3 \%$ \\
$50-64$ & $6.9 \%$ & $6.9 \%$ & $7.1 \%$ & $8.7 \%$ & $10.0 \%$ & $13.1 \%$ \\
$65-69$ & $4.7 \%$ & $5.1 \%$ & $4.6 \%$ & $5.3 \%$ & $7.9 \%$ & $10.4 \%$ \\
$70+$ & $3.3 \%$ & $3.2 \%$ & $3.4 \%$ & $3.7 \%$ & $4.1 \%$ & $5.5 \%$ \\
& $2.9 \%$ & $3.2 \%$ & $2.1 \%$ & $3.0 \%$ & $3.3 \%$ & $4.1 \%$
\end{tabular}

Table 4b: Proportion Who Wish to Work Fewer Hours for Less Pay

Year

2002

self-

Age Group employee employed employee
$16-24$

$25-49$

$50-64$

65-69

$70+$

4.5\%

$11.1 \%$

$14.8 \%$

$10.6 \%$

$7.8 \%$

$3.8 \%$

$10.0 \%$

$15.6 \%$

$15.2 \%$

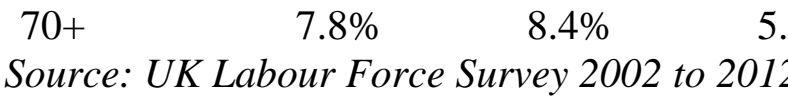

2007

selfemployed $2.9 \%$

$8.1 \%$

$14.1 \%$

$14.2 \%$

8.5\%
2012

selfemployee employed $2.5 \%$ $0.8 \%$ $6.2 \%$ $12.3 \%$ $15.2 \%$ $10.1 \%$

Table 5 shows the average change in weekly hours derived from their responses. Table $5 a$ shows the mean desired increase, while Table 5b shows the mean desired reduction. The variation by age and time in the size of the desired hours change is typically smaller than the variation in the proportion that wish to change their hours from Table 4. Among older workers, the size of the desired change in hours is greater among the self-employed than among the employed. This is consistent with the finding that the self-employed comprise different populations, some of whom face high demand for their services, while for others demand is much weaker. 
Table 5a: Mean Increase in Desired Weekly Hours

Year

2002

self-

Age Group employee employed Employee

$16-24$

25-49

50-64

65-69

$70+$
9.8

9.7

9.4

9.9

11.0
10.6

10.5

11.5

9.8

10.7

9.2

11.6

9.3

12.8

6.1
2007

selfemployed

11.5

10.5

9.9

8.5

2012

selfemployed

11.5

12.0

12.1

10.3

9.7

Table 5b: Mean Reduction in Desired Weekly Hours

\begin{tabular}{lcccccc} 
Year & \multicolumn{2}{c}{2002} & \multicolumn{2}{c}{2007} & \multicolumn{2}{c}{2012} \\
Age Group & $\begin{array}{c}\text { self- } \\
\text { employee }\end{array}$ & $\begin{array}{c}\text { employed } \\
\text { self- }\end{array}$ & $\begin{array}{c}\text { Employee } \\
\text { employed }\end{array}$ & $\begin{array}{c}\text { employee } \\
\text { employed }\end{array}$ \\
$25-49$ & 8.9 & 13.3 & 8.9 & 13.0 & 10.2 & 8.4 \\
$50-64$ & 10.0 & 13.9 & 9.9 & 12.9 & 10.1 & 12.9 \\
$65-69$ & 10.6 & 13.4 & 10.7 & 13.6 & 10.7 & 13.5 \\
$70+$ & 11.4 & 13.2 & 11.1 & 13.2 & 11.3 & 13.9 \\
& 10.4 & 11.7 & 9.2 & 12.6 & 10.3 & 11.1
\end{tabular}

Source: UK Labour Force Survey 2002 to 2012

We can use the information in Tables 4 and 5 to construct an underemployment index for older workers. The index is explained in Bell and Blanchflower (2013). It maps the unemployment rate into hours space and additionally takes account of the aggregate additional hours that a group of workers (indexed over $k$ ) say they wish to work - $\sum_{k} \tilde{h}_{k}^{U}$ and the aggregate reduction in hours (indexed over $j$ ) that a different group say they wish for $\sum_{j} \tilde{h}_{j}^{O}$. The potential hours supply of the unemployed is the product of the numbers unemployed and the average hours of the employed (predictions of the hours of the unemployed based on their characteristics yielded fitted values almost identical to the average hours of the employed). The index is given by

$$
u^{*}=\frac{U \bar{h}+\sum_{k} \tilde{h}_{k}^{U}-\sum_{j} \tilde{h}_{j}^{O}}{U \bar{h}+\sum_{i} h_{i}}
$$


Where $U$ is unemployment and $i$ is indexed over all workers. Thus the denominator is the sum of all hours worked and the potential hours of the unemployed, while the numerator comprises aggregate potential/desired hours based on the expected hours of the unemployed added to the increases in hours sought by the underemployed less the reductions in hours sought by the overemployed. When the overemployment and underemployment components are equal, the index collapses to the unemployment rate. Figure 1 shows the evolution of our index alongside the unemployment rate for all workers aged over 50 in the UK from 2002 to 2012.

Figure 1: Unemployment Rate and Underemployment Index for Workers Aged 50+ 20022012

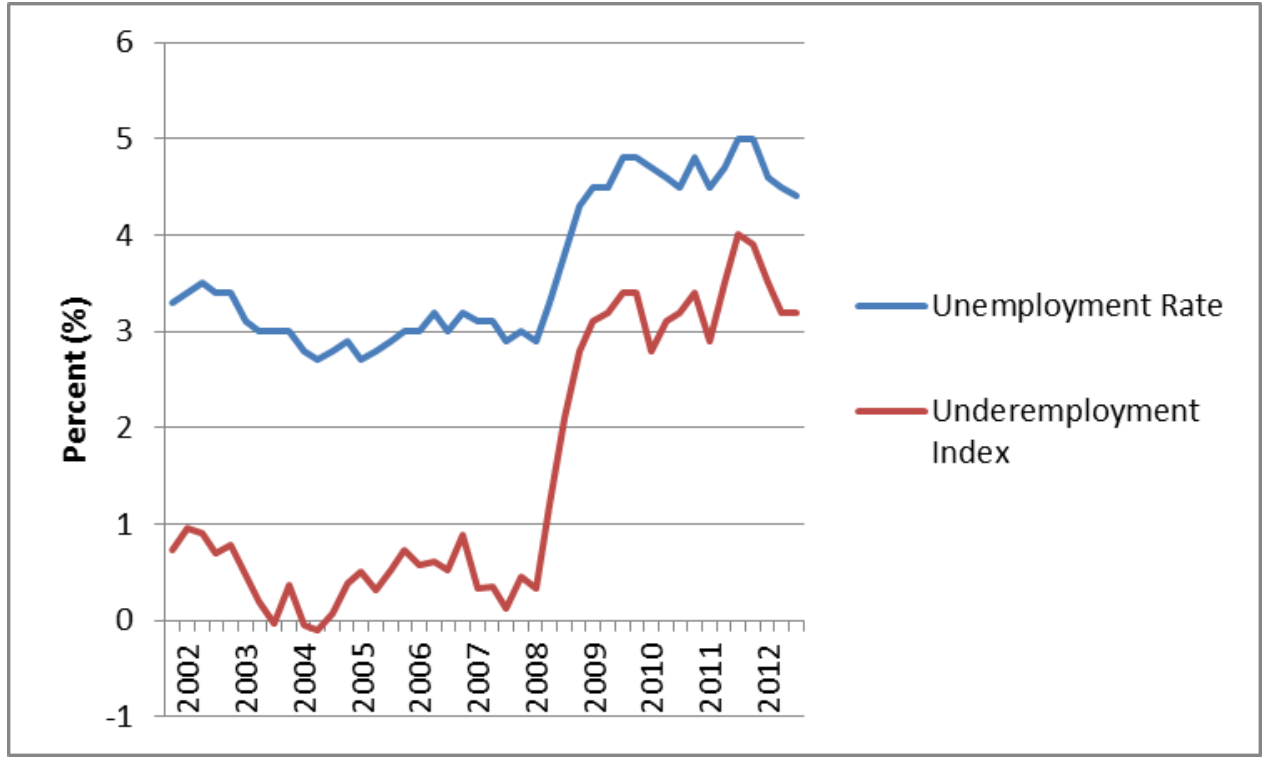

Source: UK Labour Force Survey 2002 to 2012

The underemployment index is always less than the unemployment rate for older workers. This is because the aggregate desired reduction in hours exceeds the aggregate desired increase in hours for the over 50s. This has a negative effect on the numerator in (2). The index is negative in 2004, indicating that the aggregate desired reduction in hours exceeded the hours equivalent of total unemployment among the over 50s. However, as unemployment 
increased following the 2008 recession, the gap between the unemployment rate and the underemployment index narrowed considerably as the balance shifted from older workers wishing to work fewer hours to wishing to work longer hours. As overall demand fell, the balance shifted towards older workers wishing to extend their working time. Our underemployment index thus shows that typically older workers wish to reduce their hours, but that the size of this effect is sensitive to economic conditions.

\section{Modelling Transitions}

Having shown that the older employed and self-employed workers variously express a desire to increase and to reduce their hours, we now use longitudinal data to determine whether such expressed desires to change hours affect the timing of retirement. Following the implications of the Charles \& DeCicca model, we do not presume that hours constraints on older workers are always lower bounds.

We use the longitudinal version of the LFS for this analysis, restricting the sample to those aged 50 and above. It is designed as a rotating panel, where households are observed quarterly over the course of a year. Thus, in principle, each individual in a household can be observed five times. The Office of National Statistics produces a separate, balanced, longitudinal LFS data file based on those observed at both wave 1 and wave 5 . We use observations between 2001 and 2008 on all individuals aged 50+ years who are either in paid employment or are self-employed in their wave 1 interview. Our dataset therefore precludes us from observing transitions that take longer than one year to take effect. Set against this limitation is the relatively large sample size of the LFS compared to most longitudinal surveys of ageing. We make use of some variables that are only available in the crosssectional LFS datasets by linking individual records between the longitudinal and cross- 
sectional versions of the data. The variables necessary to carry out this linkage are not available after 2009, and so our sample for this model estimation is limited to the period 2001 to 2008 .

"Underemployment" is our measure of the extra hours that workers report they would ideally like to work at their current wage rate. We create a dummy variable "underemployed" that takes the value one if individuals report that they would like to work one or more additional hours. "Overemployment" is a measure of the hours that workers report they would prefer not to work if their current employment contract permitted it. We create a dummy variable "overemployed" that takes the value one if individuals report that they would like to work one or more fewer hours in their current job, or if they report that they are currently looking for another job in order to work fewer hours. Variables measuring the number of hours that individuals would prefer to add or subtract from their employment are available. However, our focus is on the extensive margin of preferring a change in hours rather than estimating an average effect per hour. For robustness, the models presented here have also been estimated using a continuous measure of preferred hours without substantive change in the sign or significance of our results. Results are available from the authors.

Table 6 shows the profile of the sample. There is no significant difference in the average age of workers depending on their desires about working hours. Underemployed workers are more likely to be female and less likely to have a degree than overemployed workers. Consistent with our earlier analysis of the cross-sectional data, nearly four times as many workers in this age-group report being over overemployed than underemployed. However, a significant proportion of workers (3.4\%) in this age group do report being underemployed. Employed workers are slightly more likely to report being overemployed, while selfemployed workers are slightly more likely to report being underemployed, perhaps because they experience product market constraints on demand more directly than the employed. 
Whereas the entrepreneurial self-employed may be more able to control their hours, the necessity self-employed may experience demand constraints more directly.

Table 6: Descriptive Statistics

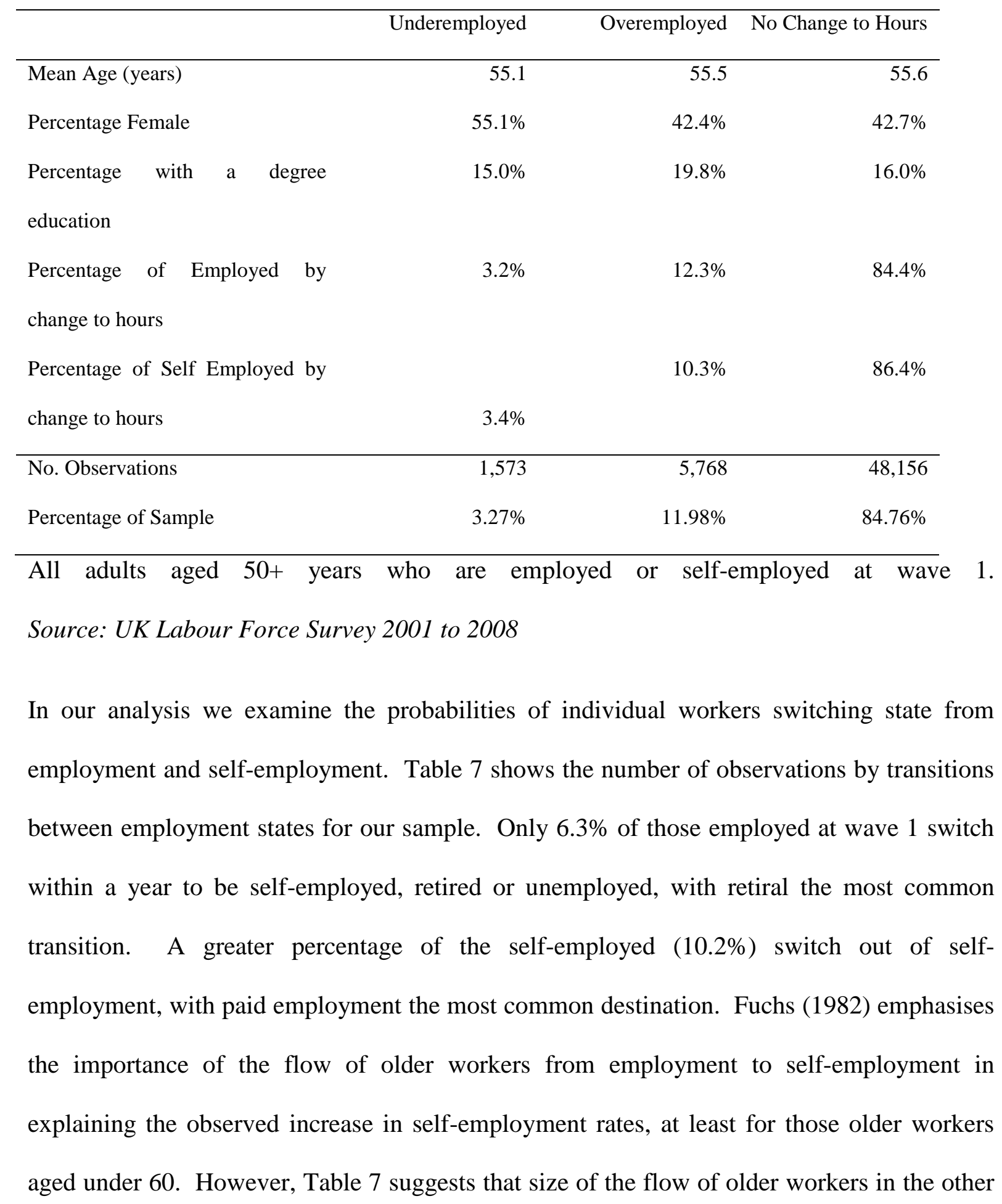


direction - from self-employment to employment - is of a similar magnitude, at least in the UK.

Table 7: Employment Transitions Between Waves

\begin{tabular}{|c|c|c|c|c|c|}
\hline \multirow[b]{2}{*}{ Status at Wave 1} & \multicolumn{5}{|c|}{ Employment Status at Wave 5} \\
\hline & Employed & Self-Employed & Retired & Unemployed & Total \\
\hline \multirow[t]{2}{*}{ Employed } & 37,546 & 570 & 1,421 & 534 & 40,071 \\
\hline & $(93.7 \%)$ & $(1.4 \%)$ & $(3.6 \%)$ & $(1.3 \%)$ & $(100 \%)$ \\
\hline \multirow[t]{2}{*}{ Self Employed } & 550 & 7,258 & 204 & 73 & 8,085 \\
\hline & $(6.8 \%)$ & $(89.8 \%)$ & $(2.5 \%)$ & $(0.9 \%)$ & $(100 \%)$ \\
\hline Total & 38,096 & 7,828 & 1,625 & 607 & 48,156 \\
\hline
\end{tabular}

Source: UK Labour Force Survey 2001 to 2008

The impact of overemployment and underemployment on transitions between labour market states is explored by estimating multinomial logistic regressions which explain the status of individuals at wave 5 conditional on them being in in paid employment or self-employment at wave 1. Controls are included in the regressions for age, gender and education. Hourly wage is included in model 1 for workers in paid employment, however wages for self employed workers are not included in model 2 as the earnings of the self-employed are not reliably measured.

Table 8 shows the results of modelling transitions from employment to all labour market states between waves 1 and 5. Employed workers who report that they would like to work fewer hours are significantly more likely to retire than those who do not. Overemployment also predicts transitions into unemployment. However, overemployed workers are no more likely than other workers to leave their jobs to take up self-employment. For workers who are self-employed, reporting being overemployed does not significantly predict transitions into any of the other states. However, underemployment and overemployment are both significant predictors of subsequent unemployment. 
Employed workers who would like additional hours at their current wage rate are less likely to retire than those who are happy with their hours of work. Self-employed workers who are underemployed, however, are significantly more likely to leave self-employment for either retirement or unemployment. It may be the case that the "necessity" self-employed give up if they cannot cover their fixed costs and then describe themselves as unemployed.

Income levels also influence probabilities of transition from employment. Higher incomes in employment at the start of the period increase the probability of transfer into both retirement and self-employment. High income earners have more degrees of freedom, partly because they are more likely to have a well-funded pension. Those on low income are more likely to switch into unemployment than those who remain employed throughout the period.

Table 8: Employment Transitions for Employed and Self Employed Workers

\begin{tabular}{|c|c|c|c|c|c|c|}
\hline \multirow{2}{*}{$\begin{array}{l}\text { Explanatory } \\
\text { Variables }\end{array}$} & \multicolumn{3}{|c|}{$\begin{array}{c}\text { Model 1: Employed in Wave } 1 \\
\text { Status in Wave 5: }\end{array}$} & \multicolumn{3}{|c|}{$\begin{array}{c}\text { Model 2: Self Employed in Wave } 1 \\
\text { Status in Wave 5: }\end{array}$} \\
\hline & Self Employed & Retired & Unemployed & Employed & Retired & Unemployed \\
\hline \multirow[t]{2}{*}{ Overemployment } & 0.132 & 0.302 & 0.348 & 0.172 & 0.298 & 0.0243 \\
\hline & $(0.141)$ & $(0.0866)^{* * *}$ & $(0.131)^{* * *}$ & -0.138 & -0.219 & -0.403 \\
\hline \multirow[t]{2}{*}{ Underemployment } & -0.189 & -0.800 & 0.413 & -0.0627 & 0.58 & 1.303 \\
\hline & $(0.324)$ & $(0.259)^{* * *}$ & $(0.228)^{*}$ & -0.256 & $(0.329)^{*}$ & $(0.384)^{* * *}$ \\
\hline \multirow[t]{2}{*}{ Hourly Wage (£) } & 0.0108 & 0.0129 & -0.0172 & - & - & - \\
\hline & $(0.00306)^{* * *}$ & $(0.00247)^{* * *}$ & $(0.00869)^{* *}$ & & & \\
\hline \multirow[t]{2}{*}{ Age } & -0.542 & 1.548 & 0.534 & 0.59 & 0.991 & -0.744 \\
\hline & $(0.300)^{*}$ & $(0.208)^{* * *}$ & $(0.366)$ & $(0.283)^{* *}$ & $(0.420)^{* *}$ & -0.672 \\
\hline \multirow[t]{2}{*}{$\mathrm{Age}^{2}$} & 0.00495 & -0.0103 & -0.00485 & -0.00542 & -0.00601 & 0.0057 \\
\hline & $(0.00259)^{*}$ & $(0.00172)^{* * *}$ & $(0.00321)$ & $(0.00245)^{* *}$ & $(0.00339)^{*}$ & -0.00582 \\
\hline \multirow[t]{2}{*}{ Female } & -0.793 & 0.491 & -0.516 & -0.00195 & 0.497 & -0.808 \\
\hline & $(0.116)^{* * *}$ & $(0.0669)^{* * *}$ & $(0.105)^{* * *}$ & -0.104 & $(0.176)^{* * *}$ & $(0.345)^{* *}$ \\
\hline \multirow[t]{2}{*}{ Degree } & 0.683 & 0.232 & 0.0462 & 0.324 & 0.215 & 0.166 \\
\hline & $(0.115)^{* * *}$ & $(0.0891)^{* * *}$ & $(0.149)$ & $(0.102)^{* * *}$ & -0.175 & -0.279 \\
\hline \multirow[t]{2}{*}{ Constant } & 10.40 & -58.80 & -18.58 & -18.59 & -41.45 & 19.19 \\
\hline & (8.637) & $(6.318)^{* * *}$ & $(10.41)^{*}$ & $(8.146)^{* *}$ & $(12.95)^{* * *}$ & -19.33 \\
\hline $\mathrm{N}$ & 31,563 & & & 8,085 & & \\
\hline
\end{tabular}

All adults aged 50+ years who are employed (Model 1) or self-employed (Model 2) at wave

1. Indicated levels of significance are: $* * *=1 \%, * *=5 \%$ and $*=10 \%$ 
With increased age, the probability of transition from employment to self-employment decreases, though not significantly. For the initially self-employed in contrast, increased age comes with a significantly greater chance of moving into paid employment. For both groups the chance of retirement increases with age, though the magnitude is greater for the employed. Females are less likely to switch into self-employment than men, and are also more likely to have retired between waves. Employees educated to degree level are more likely to switch into self-employment and also to retire earlier than those without a degree.

The underemployed self-employed are significantly more likely to be unemployed at the end of the transition period. This finding may be consistent with the notion of necessity selfemployment. The demand-constrained self-employed may find their income is below expectations and register as unemployed in the hope of finding another income source.

For employed workers, the results suggest that overemployment increases the probability of retirement. Switching to self-employment is not significantly affected by over- or underemployment. Among the employed, underemployment appears significantly to delay the decision to retire. Income constrained individuals may choose to extend their working life if the current demand for their hours falls short of their desired level.

\section{Conclusion}

This paper has explored the issues of working time constraints and labour market transitions of older workers. Contrary to the existing literature, it has found that, at least in the UK, while many older workers would prefer to work fewer hours, there exists a significant and increasing proportion of older workers who would prefer to work more hours. In theory, this would suggest that there are opportunities within this age group for welfare enhancing exchange between those who wish to work more hours and those wishing fewer hours. The 
success of any policy seeking to exploit this opportunity would be contingent on the flexibility of the labour market, including both the willingness of employers to accept the costs of reshaping their workforce and the skills flexibility of older workers. If this is a form of market failure, then government intervention to offset these costs might be justified.

We have also shown that overemployment and underemployment are associated with the timing of retirement. Consistent with the earlier literature, our investigation of the transitions made by older workers shows that overemployment is a significant predictor of early retirement. In contrast, underemployment of older employees delays retirement, perhaps because this group wish to enhance their incomes and/or pensions.

We have also established that self-employment is an important source of income for older workers, particularly those aged above the state retirement age. We have also shown that the assumption that the self-employed are more able than the employed to achieve a welfare maximizing combination of working-time and wage is questionable. Our evidence suggests that the self-employed, on average, deviate further from their desired working time than do the employed. Little attention has been given to the older self-employed in the policy debate, but since they constitute one of the fastest growing groups in the workforce, there is clearly a need for additional research on their working patterns, particularly those who might be categorised as the "necessity” self-employed. 


\section{References}

Adams, S. J. (2004). Age discrimination legislation and the employment of older workers. Labour Economics, 11(2), 219-241.

Åstebro, T., Chen, J., \& Thompson, P. (2011). Stars and misfits: Self-employment and labor market frictions. Management Science, 57(11), 1999-2017.

Bell, D.N.F. and Blanchflower, D.G. (2013). 'Underemployment Revisited', National Institute Economic Review, 224, May, F1-F15

Benz, M., \& Frey, B. S. (2008). Being Independent is a Great Thing: Subjective Evaluations of Self-Employment and Hierarchy. Economica, 75(298), 362-383.

Oswald, A. J., \& Blanchflower, D. G. (1998). What makes an entrepreneur. Journal of Labor Economics, 16(1), 26-60.

Blanchflower, D. G. (2000). Self-employment in OECD countries. Labour Economics, 7(5), 471-505

Block, J., \& Koellinger, P. (2009). I can't get no satisfaction-Necessity entrepreneurship and procedural utility. Kyklos, 62(2), 191-209

Charles, K. K., \& DeCicca, P. (2007). Hours flexibility and retirement. Economic Inquiry, 45(2), 251-267.

Eichhorst, W. (2011). The transition from work to retirement. IZA Discussion Paper

Fairlie, R. W., \& Meyer, B. D. (1996). Ethnic and racial self-employment differences and possible explanations. Journal of Human Resources, 757-793. 
Fuchs, Victor R. (1982). Self-Employment and Labor Force Participation of Older Males. Journal of Human Resources, 17(3), 339-57.

Gielen, A. C. (2009). Working hours flexibility and older workers' labor supply. Oxford economic papers, 61(2), 240-274.

Hundley, Greg, 2001. Why and when are the self-employed more satisfied with their work? Industrial Relations 40 (2), 293-316.

Kanabar, R. (2012). Unretirement in England: An empirical perspective. Department of Economics, University of York.

Lahey, J. (2006). State age protection laws and the age discrimination in employment act (Working Paper w12048). National Bureau of Economic Research.

Lombard, K. V. (2001). Female self-employment and demand for flexible, nonstandard work schedules. Economic Inquiry, 39(2), 214-237.

Meadows, P. (2003) Retirement Ages in the UK: A Review of the Literature, Employment Relations Research Series No. 18. London: Department of Trade and Industry

Moffitt, R. (1982). The Tobit model, hours of work and institutional constraints. The Review of Economics and Statistics, 64(3), 510-515.

Naylor, R. A. (2003). Labour supply, efficient bargains and countervailing power. Competition, monopoly and corporate governance: Essays in honour of Keith Cowling, 101-16.

Pencavel, J. (1986). Labor supply of men: a survey. Handbook of labor economics, 1(Part 1), 3-102 
van Rooij, M. C., Lusardi, A., \& Alessie, R. J. (2012). Financial Literacy, Retirement Planning and Household Wealth. The Economic Journal, 122(560), 449-478

Vickerstaff, S., Baldock, J., Cox, J. and Keen, L. (2004). Happy retirement?: the impact of employers' policies and practice on the process of retirement. The Policy Press. 